\title{
The EU Services Directive, German Labour Market Regulation and I nstitutional Change
}

\author{
John Leslie \\ Victoria University of Wellington \\ John.Leslie@vuw.ac.nz
}

\begin{abstract}
How does extending markets across national borders impact national institutions regulating labour markets? This paper addresses this question by analysing resistance in Germany to the European Commission's draft Directive on an Internal Market for Services (COM(2004) 2 final/3). It demonstrates how the Commission's initial attempt to integrate European service markets threatened to accelerate changes in the institutional structure of post-war German industrial relations. The paper shows how a broad spectrum of social and political interests in Germany united in successful opposition to this threat. It also demonstrates, however, that this resistance only postponed institutional reform in German labour markets and pushed the reform process-temporarily-from European to German legislative arenas. This study demonstrates that European market liberalisation, rather than driving the German state from labour markets, is pushing it to take a more active role in regulating employment. It also provides observations about processes of institutional change.
\end{abstract}

Few pieces of European legislation have focused political attention in Germany like the so-called 'Bolkestein Draft'1 of the European Commission's directive for creating an internal market in services. This draft highlighted the impact of European integration on German labour markets. Its supportersinside and outside the FRG-viewed it as a cornerstone of the Lisbon Agenda and efforts to turn the EU into the world's most competitive knowledge-based economy. ${ }^{2}$ Opponents portrayed it as an engine of 'social and legal dumping [that] calls into question our labour laws and public services.' 3 Underlying both visions is the expectation that European service market integration is liberalising labour market regulations in Germany and Europe, more generally. These perspectives mirror concerns about the broader liberalising impact of European integration ${ }^{4}$ and globalisation. ${ }^{5}$

\footnotetext{
${ }^{1} \mathrm{COM}(2004) 2 \mathrm{final} / 3$ 'Proposal for a directive of the European Parliament and of the Council on service in the internal market,' March 5, 2004, available at: <http:// eurlex.europa.eu/ LexUriServ/ LexUriServ.do?uri=COM:2004:0002:FIN:EN:PDF>.

$2 \operatorname{COM}(2002) 441$ final 'Report from the Commission to the Council and the European Parliament on the state of the internal market for services', July 30, 2002, available at: <http:// eur-lex.europa.eu/ LexUriServ/ LexUriServ.do?uri=COM:2002:0441:FIN:EN:PDF>. ${ }^{3}$ D. de Villepin, cited in Open Europe, The services directive: Can Europe deliver? , p. 13, available at: <http:// www.openeurope.org.uk/ research/ services.pdf>.

${ }^{4}$ F. W Scharpf, Governing in Europe: Effective and democratic?, Oxford University Press, USA, 1999.
} 
This paper investigates the German response to European attempts to liberalise labour market regulations in European service markets, particularly wage-setting mechanisms. It demonstrates that service sector integration has increased pressure on an already liberalising regulatory regime, driving the German state deeper into labour markets. Furthermore, it is the interests of German labour and capital that are driving renewed state intervention in labour markets. As these processes are on-going, the conclusions of this paper must remain preliminary. Nonetheless it demonstrates that, even as liberalisation proceeds, actors from across the political spectrum have fought to keep the process of re-regulating labour markets in German hands.

This paper proceeds in three sections. The first section untangles the reality of the draft Services Directive from the hyperbolic rhetoric surrounding it throughout Western Europe, but, particularly, in Germany. The 'Bolkestein' Draft departed radically from previous practice by extending the 'country-oforigin' principle generally across service sectors. However, it also included considerable protection for many existing national practices, particularly in the regulation of labour markets. A second section demonstrates why German resistance to the draft was so strong. The regulation of labour markets in Germany left it uniquely exposed to the effects of the application of the country-of-origin principle, even as the Red-Green government undertook its own liberalising reforms in service sectors. Integration of European service markets is forcing change in institutions to which employer and employee interests are bound. Rather than resolve the conflicts that arise from institutional change in a struggle over European legislation, however, German politicians, from the Left and the Right, fought successfully to reframe the Services Directive, remove the country-of-origin principle and limit the directive's scope. Their actions, however, postponed rather than resolved a looming fight over institutional change. They transferred conflicttemporarily - to the domestic German political arena. The third section analyses the possibilities for reform of German labour market institutions before the single market for services comes into being in 2010 and the restrictions on cross-national employment of CEE citizens end in 2011. It demonstrates that, while wholesale liberalisation and decentralisation of German labour markets remains a possibility, the interests of employees and employers point toward state action to reinforce existing institutions and/ or direct regulation of labour relations. A concluding section suggests some implications of this development for our understanding of European integration as well as of the process and direction of institutional change.

\footnotetext{
${ }^{5}$ S. Berger and R. P Dore, National diversity and global capitalism, Cornell University Press, 1996; W. Streeck and K. A Thelen, 'Introduction: Institutional change in advanced political economies' in W. Streeck and K. Thelen (eds.), Beyond continuity: Institutional change in advanced political economies, Oxford University Press, USA, 2005, pp. 1-39.
} 


\section{The I nternal Market for Services, the' Bolkestein' Draft and Hyperbole}

The Commission published its draft directive in J anuary 2004. In the course of 2004-2005 the draft became embroiled in the controversies surrounding rising unemployment, Central and Eastern European enlargement and ratification of the Constitutional Treaty-throughout Europe-as well as the Schröder Government's Agenda 2010 labour market reforms within Germany. In this context, hyperbolic rhetoric consumed reasoned analysis of the directive's provisions and consequences. This was especially true of the directive's anticipated impact on labour markets. This section offers a brief sketch of the inflated expectations that surrounded the draft before providing more detail about its actual provisions with regard to labour regulations and the country-of-origin principle in particular.

\section{Hyperbole}

The Commission started the rhetorical inflation by connecting the directive to radical social transformation. Its 2002 report on strategies for service sector integration concluded that the goal set by the Lisbon Council to make the European economy the most competitive in the world cannot be met unless sweeping changes are made to remove barriers to cross-border services in the near future.' 6 The Commission marketed the directive as the centrepiece in an effort to turn Europe - within a decade-into an 'information society'. To ease fears about social upheaval, the Commission's 'Extended Impact Assessment' suggested that 'creation of a well-functioning Internal Market in services...could result in gains on an equivalent scale' to those realised since the creation of the Internal Market in 1992.7 The Commission's estimate of gains since 1992 was 1.8\% growth in GDP and 2.5 million jobs. Because, as the Commission repeated tirelessly, services 'account for $70 \%$ of GDP and employment' in the EU, equivalent gains in the service sector would-it was implied-yield greater gains in growth and employment. ${ }^{8}$ In a less publicised assessment produced for the Commission, however, Copenhagen Economics calculated the impact of service integration as a $0.6-0.7 \%$ of GDP growth and an employment increase of 'up to 600,000 ' jobs. ${ }^{9}$ The Commission justified powerful legislative 'medicine' (discussed below) by inflating expectations about its impact on growth and employment.

Once the Commission connected the directive to social transformation, opponents questioned the costs of the directive and the intentions underlying them. The application of the country-of-origin principle across service sectors

\footnotetext{
${ }^{6} \mathrm{COM}(2002) 441$ final. p. 9.

${ }^{7}$ SEC(2004)2 ‘Commission Staff Working Paper: Extended impact assessment of proposal for a directive on services in the internal market', J anuary 13, 2004, p. 29 (emphasis added).

${ }^{8} \mathrm{COM}(2002) 441$ final op. cit., p. 5; $\operatorname{COM}(2004) 2$ final/ 3 op. cit., p. 5.

9 Copenhagen Economics, Economic assessment of the barriers to the internal market for services: final report, Copenhagen, January 2005, pp.12-13, available at: <http:// ec.europa.eu/internal_market/services/docs/ services-dir/studies/2005-01-cphstudy_en.pdf $>$.
} 
galvanised those who feared the directive's impact on environmental and consumer protections, public provision of services and employment standards. In the context of the French referendum on the Constitutional Treaty and the 2004 Enlargement, the directive was instrumentalised to fan popular fears about the impact of service sector integration on labour markets. The Accession treaty's 'freedom of services' clause had produced-in the popular imagination, at least-an invasion of Polish plumbers, roofers and butchers willing to replace their French and German counterparts for 'dumping wages'.10 Opponents like TUC General Secretary Brendan Barber played on these fears, suggesting that the services directive 'would fire the starting gun on a race to the bottom' creating 'flags of convenience' in every part of the European service sector. ${ }^{11}$ European Trade Union Confederation General Secretary J ohn Monks argued that the Services Directive as proposed by the Commission.. fosters regime competition, allowing 25 and soon 28 member states to compete on each other's territory at the expense of quality public and social services, the environment, industrial relations systems and workers' rights'.12 Indeed, trade unionists across Europe found the draft to be an unexpectedly powerful instrument for mobilising public opinion on EU policy. ${ }^{13}$

The reality of the draft's impact likely stood somewhere between visions of liberal utopia and the Satanic Mill. The draft was a complex document combining regulations in three areas. ${ }^{14}$ First, it set guidelines mandating that member states create 'single points of contact', 'electronic means' and specific authorisation procedures to simplify the administrative hurdles for establishing service businesses. ${ }^{15}$ It also prohibited certain legal and administrative requirements as preconditions for establishment. ${ }^{16}$ Second, the draft directive sought to build trust between member states by harmonising consumer protection legislation, particularly by specifying areas for enhanced cooperation among national authorities and by drawing up codes of conduct and measures to promote the quality of services. ${ }^{17}$ It was the directive's third area of focus, abolition of barriers to the free movement of services that provoked the greatest resistance.

The Bolkestein Draft introduced two innovations in the way the Commission sought to regulate cross-border trade in services: the country-of-origin

10 M. Deggerich, 'Der Osten kommt', Der Spiegel/Spiegel Online, February 14, 2005, p. 32, available at: <http:// www.spiegel.de/ spiegel/ print/ d-39367919.html >; J. Mey, 'Die Crux der Dienstleistungsfreiheit', Frankfurter Rundschau, J anuary 7, 2005, sec. Wirtschaft, p. 11.

${ }^{11}$ Trade Union Congress (TUC), 'Some movement on services directive not enough for unions', European Review, April 2005, p. 4.

${ }^{12} \mathrm{~J}$. Monks, 'Letter to Members of the Internal Market Committee of the European Parliament regarding Draft Directive on Services in the Internal Market', October 3, 2005, available at: <http:// www.etuc.org/IMG/pdf/letter_to_IMCO_031005_EN-3.pdf>.

13 C. Fischbach-Pyttel, '2005 priorities! WORKİNG TIME and SERVICES DIRECTIVE EPSU', European Federation of Public Service Unions, 2005, available at: $<h t t p: / /$ www.epsu.org/a/ 895>.

14 United Kingdom Department of Trade and Industry (DTI), 'EU directive on services in the internal market: consultation document', 2005, available at: <http:// www.berr.gov.uk/ files/ file23133.pdf>.

${ }_{15}^{15}$ DTI Ibid., p. 2.

16 DTI Ibid.

${ }^{17}$ DTI Ibid. 
principle and the simultaneous regulation of multiple (service) sectors. ${ }^{18}$ In Article 16, the country-of-origin principle subjected service providers 'only to the national provisions of their Member State of origin' and made the Member State of origin 'responsible for supervising the provider and the services provided by him, including services provided by him in another member state. 19 To reinforce country-of-origin legislation, the draft's Art 24 enumerated specific measures member states could not impose to control the operation of foreign firms on their soil. ${ }^{20}$ As constructed in the Bolkestein draft, the country-of-origin principle exceeded the liberalising impact even of 'mutual recognition,' as that principle evolved in practice. ${ }^{21}$

In fact, the draft's radical departure from past practice was not the country-oforigin principle per se, but its application across multiple service sectors. ${ }^{22}$ Previously, the Commission had included the country-of-origin principle in directives regulating 'television without frontiers' (89/552/EC, revised 97/36/EC), electronic signatures (1999/93/EC) and e-commerce (2000/31/EC). The Bolkestein Draft however, did not set regulatory guidelines for an individual sector, but rather applied the country-of-origin principle to 'services' generally. It permitted derogations for specific sectors and activities, but liberalisation was the default option. ${ }^{23}$ This approach was novel in two ways. First, past integration of service markets had permitted member states to liberalise individual sectors and then harmonise regulations at the European level. ${ }^{24}$ The sweeping application of the country-of-origin principle made harmonisation secondary, clearly placing national deregulation above supranational re-regulation. ${ }^{25}$ Second, while previous directives applied the country-of-origin principle to sectors where the service itself crossed borders (e.g. television and e-commerce), the Bolkestein Draft applied it to sectors where both the service and the provider crossed borders. ${ }^{26}$ Skeptical observers questioned the capacity and incentive of member states of establishment to regulate the activities of service providers abroad. They argued that sweeping application of the country-of-origin principle would confuse jurisdictions and erode service quality as well as employee protection.

\footnotetext{
${ }^{18}$ B. De Witte, 'Setting the Scene: How did Services get to Bolkestein and Why?', European University Institute Working Papers, Vol. 20, No. 11, 2007; Group of the Progressive Alliance of Socialists \& Democrats in the European Parliament (S \& D), 'Policies: Services Directive', Group of the Progressive Alliance of Socialists and Democrats in the European Parliament (S \& D), October 7, 2008, available at:

<http:// www.socialistgroup.eu/gpes/ public/ polidetail.htm?topicid=614\&section=POL\&categ ory=POLI $>$; K. Nicolaïdis and S. K. Schmidt, 'Mutual recognition 'on trial': the long road to services liberalization', J ournal of European Public Policy Vol. 14, No. 5, August 2007, pp. 717-738.

${ }_{19} \mathrm{COM}(2004) 2$ final/3, op. cit., Art. 16, Para $2 \& 3$.

${ }_{20} \mathrm{COM}(2004) 2 \mathrm{final} / 3$ Art 24 Ibid.

${ }^{21} \mathrm{C}-\mathrm{M}$. Jonsson, 'Comparing the mutual recognition principle and the country of origin principle', Paper for the ETUC Working Group on Social Policy and Legislation (May 25, 2005); Nicolaïdis and Schmidt, op. cit.

22 De Witte, op. cit.; S \&D, op. cit.

${ }^{23} \operatorname{COM}(2004) 2$ final/3, op. cit., Arts 16-19.

${ }^{24}$ Nicolaïdis and Schmidt, op. cit.

25 De Witte, op. cit.

${ }^{26} \mathrm{~J}$ onsson, op. cit.
} 
Anticipating these concerns, the draft's authors permitted derogation from the country-of-origin principle in a substantial list of sectors and activities. Article 17 permitted specific, general derogation for, among other things: postal services; electricity, gas, and water distribution; recognition of professional qualifications; notary services; matters of public health, policy and security; as well as some sectors and activities covered in other European legislation. Most importantly, Art.17(5) insulated labour market regulations from regime competition by exempting all 'matters covered by Directive 96/71/EC,' the Posted Workers Directive, from the country-of-origin principle. The Posted Workers Directive, accommodates diverse national labour market regimes within overarching European guidelines. It directs Member States-rather than the country-of-origin-to guarantee the terms and conditions of employment on their territory, covering: maximum work/minimum rest periods; paid holidays; minimum rates of pay; temporary employment; health, safety and hygiene at work; and discrimination. ${ }^{27}$ In setting these minimum standards the Directive recognises the validity of national regulations regardless of whether they were laid down by law, regulation or administrative provision and/or by collective agreements or arbitration awards which have been declared universally applicable....'28 Member states that lacked a system for declaring collective agreements universally applicable could base minimum employment standards on

collective agreements or arbitration awards which are generally applicable to all similar undertakings in the geographical area and in the profession or industry concerned, and/ or collective agreements which have been concluded by the most representative employers' and labour organisations at national level and which are applied throughout the national territory, provided that their application...ensures equality of treatment.... ${ }^{29}$

Thus, by subordinating labour market regulation to the Posted Workers Directive on the issue, the Bolkestein Draft recognised the dominance of host countries' labour market regulations. The Bolkestein Draft confused this relationship, however, by limiting the mechanisms Member States could use to monitor the employment of posted workers. 30

Even with such ambiguities, opponents-like the authors themselves-inflated the likely impact of service market integration and the Bolkestein Draft on national environmental, consumer and labour regulations. By applying the country-of-origin principle across the broad category of 'services,' the authors sought an ambitious, and ill-timed, acceleration of market integration. ${ }^{31}$ They intended to make liberalisation the default mechanism for service sector integration. 32 To make liberalisation palatable, however, they embedded protections for diverse national welfare and regulatory systems in legislation.

27 'Directive 96/71/EC of the European Parliament and of the Council of 16 December 1996 concerning the posting of workers in the framework of the provision of services,' Art 3(1) text/html; charset=UTF-8, Eur-Lex, available at:

<http:// eur-lex.europa.eu/LexUriServ/ LexUriServ.do?uri=CELEX:31996L0071:EN:HTML>.

28 96/ 71/ EC, Ibid, Art 3(1).

29 96/ 71/ EC, Ibid, Art 3(8), emphasis added.

$30 \mathrm{COM}(2004) 2$ final/3, op. cit., Arts 24/ 25.

31 Nicolaïdis and Schmidt, op. cit.

32 Ibid. 
In an environment characterised by unprecedented unemployment, polarised debates about the Constitutional Treaty and social insecurities associated with the Eastern Enlargement, such nuances were easily overlooked. Consequently, a broad and well organised opposition succeeded in forcing removal of the country-of-origin principle and labour regulation, in general, from the final directive. The fiercest opposition to the draft erupted in Germany, where the major political parties, unions and even many employers coalesced to revise the legislation. To understand the intensity of the German reaction, one must understand the peculiar impact of European integration on Germany's evolving labour markets. The next section demonstrates this impact and why Germans wish to manage it domestically rather than through EU legislation.

\section{Service Integration, the Peculiarity of German Labour Markets and German Resistance}

The Bolkestein Draft created special problems and, therefore, met greater resistance in Germany. German politicians led resistance to the draft in the European Parliament and German governments-under both Social Democratic and Christian Democratic chancellors-led resistance in the Council. In German society, unions led the fight against the draft, while employers were - at best-ambivalent about it. The strength of this opposition reflects the vulnerability of Germany's changing labour markets to EU integration. The fact that in many sectors German labour markets are heterogeneous' makes them more sensitive to the effects of integration. Labour markets are heterogeneous in the sense that employment relations in some firms in a sector are governed by collective agreements negotiated in a centralised, 'corporatist' labour market regime, while employment relations in other firms - in the same sector-are governed by decentralised agreements 'negotiated' between individual employers and employees. ${ }^{33}$ The problem for Germans is that, while European regulations accommodate 'corporatist', 'statist' or liberal' labour market regimes, they cannot abide discrimination or rules that permit domestic employers options that are unavailable to nonGerman employers. This raises the possibility that integration will permit service providers to enter German markets outside of employers associations and the centralised collective bargaining system, thereby hastening its demise. The following explains the heterogeneous' regulation of German labour markets and outlines the coalition of social and political actors provoked by the draft Services Directive.

\section{‘Heterogeneous' labour market regulations in Germany}

The regulation of German labour markets is unique among EU member states. Of the 25 EU member states in 2005, eighteen had some form of legislated minimum wage. Six of the remaining seven maintain the 'functional

33 R. Bispinck and C. Schäfer, Niedriglöhne und Mindesteinkommen: Daten und Diskussionen in Deutschland' in T. Schulten, R. Bispinck, and C. Schäfer (eds.), Mindestlöhne in Europa, Hamburg: VSA-Verlag, 2006, pp. 269-301; and T. Schulten, 'Gesetzliche und tarifvertragliche Mindestlöhne in Europa-ein internationaler Überblick,' in T. Schulten, R. Bispinck, and C. Schäfer (eds.), Mindestlöhne in Europa, Hamburg: VSA-Verlag, 2006, pp. 927. 
equivalent' of a universal minimum wage. ${ }^{34}$ These include the Scandinavian systems (Denmark, Finland and Sweden) in which union management of unemployment insurance programs, the so-called 'Ghent System,' ensures that union membership and collective bargaining agreements encompass more than $90 \%$ of employees. ${ }^{35}$ Germany has neither a legal minimum wage, nor universal coverage of employees under collective agreements. Rather, the post-war industrial relations system is built on collective bargaining between sectoral unions and employers' associations who defend a tradition of 'wage autonomy' [Tarifautonomie] that insulates their negotiations from government influence. Even as unions and employers associations defended this system, however, an increasing number of firms have left employers associations and sectoral negotiations. The causes for their flight stretch back to the 1980s, but the movement has accelerated since unification. ${ }^{36}$ Erosion of the post-war system leaves a growing number of employees outside collective agreements in many sectors. ${ }^{37}$ Table 1 illustrates this development over the past decade.

\section{Table 1}

\section{$\%$ of Employees in Firms Bound by Collective Bargaining Agreements (West and East Germany 1996-2006) 38}

\begin{tabular}{|l|l|l|l|l|l|l|l|l|l|}
\hline & 1996 & 1998 & 2000 & 2001 & 2002 & 2003 & 2004 & 2005 & 2006 \\
\hline $\begin{array}{l}\text { West } \\
\text { Germany }\end{array}$ & 69 & 68 & 63 & 63 & 63 & 62 & 61 & 59 & 57 \\
\hline $\begin{array}{l}\text { East } \\
\text { Germany }\end{array}$ & 56 & 51 & 46 & 44 & 43 & 43 & 41 & 42 & 41 \\
\hline
\end{tabular}

This development leaves Germany with a heterogeneous industrial relations system in which large numbers of employees remain inside the old corporatist system, while another large group finds itself outside it. Furthermore, 'insiders' and 'outsiders' are concentrated in different sectors. Large firms in core exporting industries tend to remain in the traditional, sectoral bargaining system, while smaller enterprises, often in the service sector and, more-often-

34 Schulten, Ibid.

35 Ibid., p. 18.

36 S. J. Silvia, 'German Unification and Emerging Divisions within German Employers' Associations: Cause or Catalyst?', Comparative Politics, Vol. 29, No. 2, 1997, pp. 187- 208; K. Thelen, 'Why German employers cannot bring themselves to dismantle the German model' in T. Iverson, J. Pontusson, and D. Soskice (eds.), Unions, employers, and central banks: Macroeconomic coordination and institutional change in social market economies, Cambridge: Cambridge University Press, 2000, pp. 138- 169.

${ }^{37}$ A. Hassel, The erosion of the German system of industrial relations', Models of Capitalism: Debating Strengths and Weaknesses, Vol. 37, No. 3, 1999, p. 323; The erosion continues: reply', British J ournal of Industrial Relations, Vol. 40, 2002, pp. 309-317; and W. Streeck and A. Hassel, 'The crumbling pillars of social partnership', West European Politics Vol. 26, No. 4, 2003, pp. 101- 124.

38 G. Fischer et al., Standortbedingungen und Beschäftigung in den Regionen West- und Ostdeutschlands: Ergebnisse des IAB-Betriebspanels 2006, IAB Forschungsbericht, 2007, available at:

<http:// doku.iab.de/ forschungsbericht/ 2007/ fb0507.pdf>. 
than-not, in East Germany are covered neither by sectoral or company-level collective agreements. ${ }^{39}$ Wages and security tend to be lower in these so-called 'blank spaces,' where there is no collective bargaining, although low' wages are also found in sectors with collective bargaining. 40 This dichotomy of liberal and corporatist structures gives German labour markets a heterogeneous' quality that marks an increasingly important division in German society.

Labour market reforms introduced by the 'Red-Green' government of Gerhard Schröder also contributed to the heterogeneity of German labour markets. After unification, financing of Germany's post-war welfare insurance schemes through employer and employee payroll contributions had the perverse effect of raising labour costs with rising unemployment. ${ }^{41}$ The Red-Green government attempted to reverse this adverse relationship, first, through corporatist coordination in the Bündnis für Arbeit (Alliance for Work) and, then, through legislated reform. ${ }^{42}$ The government's Agenda 2010 legislation sought to move people back into the labour force by reducing unemployment payments and their duration. 43 The policies of Agenda 2010 liberalised German labour markets in three ways. First, the German state assumed a greater role in areas of labour market regulation where corporatist actorsunions and employers' association-traditionally played a central role in policy formation and implementation. Second, reforms shifted much of the risk of unemployment onto individuals. Finally, reforms further expanded low-wage employment that is often in service sectors and not covered by collective agreements.

European integration created problems for German labour market regulation long before introduction of the draft Services Directive or Agenda 2010.44 The Single European Market and the Posted Workers Directive (96/ 71/ EC) forced German legislators to manage the problems of cross-border service provision in the 1990s. One response was the Posted Workers Law (AEntG 1996, amended in 1999 and 2009), permitting Labour Ministers to declare contractual agreements, where unions and employers associations negotiated contracts covering the entire country, binding for all employers and

\footnotetext{
39 Hassel, The erosion,' op. cit.

40 Bispinck and Schäfer, op. cit.

41 G. Esping-Andersen, Welfare states without work: the impasse of labour shedding and familialism in Continental European social policy' in G. Esping-Andersen (ed.), Welfare states in transition: National adaptations in global economies, London: Sage Publications, 1996, 66- 87; P. Manow and E. Seils, 'Adjusting badly: The German welfare state, structural change, and the open economy' in F. Scharpf and V. Schmidt (ed.), Welfare and work in the open economy, vol. 2, 2000, Oxford and New York: Oxford University Press, 2000, pp. 264- 307; and W. Streeck and C. Trampusch, 'Economic reform and the political economy of the German welfare state', German Politics, Vol.14, No. 2, 2005, pp. 174-195.

$42 \mathrm{~J}$. N. Ziegler and J. Leslie 'Policy experimentation and the search for institutional change: The politics of Red-Green reform in Germany', UC Berkeley: Institute of European Studies, available at: <http:/ / www.escholarship.org/ uc/item/ 5pq840bv>.

${ }^{43} \mathrm{~V}$. Steiner, 'Social welfare reform and the low-wage labor market in Germany: what works and what doesn't', Applied Economics Quarterly Supplement, Vol. 55, 2004, pp. 57- 78.

44 G. Menz, 'Re-regulating the Single Market: national varieties of capitalism and their responses to Europeanization', J ournal of European Public Policy, Vol. 10, No. 4, 2003, pp. 532- 555.
} 
employees-domestic or foreign-operating in a given sector. ${ }^{45}$ Resistance to broader state intervention, however, limited the law's scope, originally, to the construction industry. ${ }^{46}$ In 2007 it was extended to salvage, roofing, cleaning and painting services. In 2008 the Merkel government extended the law to letter couriers. In 2009, six more low-wage sectors were brought under the law, including private security guards, rubbish disposal, personal home care and laundry services. The 2009 reforms also substantially eased the restrictions on Labour Ministers' ability to declare collective agreements universally binding. Gaps in collective bargaining, however, spread well beyond these sectors, and the impending integration of labour markets as a result of Central and East European Accession and the Services Directive represents an uncertain potential to accelerate erosion of the post-war industrial relations system.

Integration of labour markets confronts German unions and employers associations with a dilemma. Erosion of the post-war industrial relations system has left parallel corporatist and liberal employment regimes in many sectors. European legislation, however, proscribes discrimination against nonGerman employers. Thus, service providers cannot be prevented from entering German markets under the liberal regime as long as this option is available to domestic service providers. An influx of service providers operating under decentralised, liberal labour market rules might hasten the erosion of the legacy corporatist system and exacerbate tensions between labour market 'insiders' and 'outsiders.' This left Germans three choices. The first two options saw the state intervening in labour markets: to legislate minimum employment standards or to reinforce the old collective bargain system through, for example, extension of the Posted Workers Law (AEntG). The third option would be to accept liberalisation without domestic reform and test whether existing institutions could withstand market competition. Because this choice has the potential to redistribute wealth and power significantly, it has provoked major conflict. ${ }^{47}$ Powerful social and political interests in Germany coalesced to postpone the choice and transfer the decision from EU decision-making institutions to the domestic legislative arena in hope of finding a domestic solution to labour market reform before European service and labour markets open. Doing so, however, has meant that any constraints imposed on domestic labour market legislation by the Services Directive would have to be removed.

\section{German resistance to the draft directive}

A broad coalition opposed the country-of-origin principle in Germany. Union resistance to European legislation that might hasten erosion of Germany's corporatist industrial relations system is less-than-surprising. German employers, however, were also ambivalent about the draft directive and did

\footnotetext{
45 R. Bispinck and T. Schulten, 'Aktuelle Mindestlohndebatte: Branchenlösungen oder gesetzlicher Mindestlohn?', WSI Mitteilungen, No. 3, 2008, pp. 151-158.

46 Hans Boeckler Foundation, 'Gesetzliche Stützen für das Tarifsystem', Boecklerimpuls 9, 2006, p.2.

47 S. K. Schmidt, When Efficiency Results in Redistribution: The Conflict over the Single Services Market', West European Politics, Vol. 32, No. 4, 2009, pp. 847- 865.
} 
nothing to support a move toward liberalisation of labour markets at the European level. Absent support from employers and in the face of strong union opposition, the major parties of the Centre-Left, the SPD, and CentreRight, CDU/CSU, lined up against the Bolkestein Draft. The following explains the diverse interests that converged in opposition to the draft in Germany.

German unions have consistently opposed a legislated expansion of the low wage sector in principle even as erosion of the post-war industrial relations system has created one in fact. Contrary to its image as an egalitarian, high wage society, many Germans work for low' wages. Definitions of what constitutes low' wages vary. Using the OECD definition of $67 \%$ of the median wage as the threshold for low' wages, $22.6 \%$ of all employed Germans fell into this category in 2006.48 Furthermore, wage spread in Germany in 2005 was almost identical to Great Britain. ${ }^{49}$ 'Low' wage employment exists in sectors covered by collective agreements as well as those outside the contract system. 50 The number of Germans falling into this category, however, has increased parallel to the erosion of post-war industrial relations institutions and is concentrated in those sectors-services-and regions-East Germanywhere these institutions are weakest. 51 While unions disagree among themselves about how to combat low wages, 52 they agree that an influx of foreign employers operating outside the corporatist industrial relations system is likely to expand low wage employment. Accordingly, the German Union Federation (DGB) deemed the country-of-origin principle and mutual recognition inappropriate means for large-scale market integration. These mechanisms, it argued, should be reserved for specific sectors where minimum standards and/ or a certain level of harmonisation already existed. 53 Extrapolating from this conclusion, the DGB demanded removal of the country-of-origin principle (Article 16) from the draft and specification in Articles 1 (the directive's goals) and 2 (the directive's scope) that questions of social and labour law fall outside the directive's jurisdiction. ${ }^{54}$ In February 2006 the European Parliament adopted these positions in amendments that became the basis for the final directive.

German employers' ambivalence toward the Commission draft is even more interesting than union resistance. From an orthodox liberal perspective, German employers should have supported the country-of-origin principle and liberalisation as a means of reducing labour market 'rigidities.' Yet, among German employers' associations only the representative of family-owned,

\footnotetext{
48 Bispinck and Schulten, op. cit.

49 Kai Burmeister, 'Mindestlöhne in Europa: Vielfältige Regelungen, unterschiedliche Erfahrungen!', IG Metall Wirtschaftspolitische Informationen, No. 12, 2006, p. 3.

50 Bispinck and Schäfer, op. cit.

${ }^{51}$ T. Kalina and C. Weinkopf, 'Weitere Zunahme der Niedriglohnbeschläftigung: 2006 bereits rund 6, 5 Millionen Beschäftigte betroffen', Institut Arbeit und Qualifikation. IAQ-Report, No. 1, 2008.

$52 \mathrm{~J}$. Wiedemuth, Für einen gesetzlichen Mindestlohn-Eckpunkte eines Einführungs- und Umsetzungskonzepts' in G. Sterkel, T. Schulten, and J. Wiedemuth (eds.), Mindestlöhne gegen Lohndumping, Hamburg: VSA-Verlag, 2006, pp. 284-93.

53 DGB 'Positionspapier: EU-Richtlinie 'Dienstleistungen im Binnenmarkt' Konfliktfelder aus Sicht des DGB', April 2005, No. 4, available at: <http:// www.elisabethschroedter.de/ downloads/ DGB-Positionspapier\%20Dienstleistungsrichtlinie\%2004-05.pdf>. 54 DGB Ibid., p. 13.
} 
small and medium sized enterprises (Arbeitsgemeinschaft Selbständiger Unternehmer - ASU) made a liberal defence of the country-of-origin principle. 55 Opposition to the draft came most clearly from the Central Association of German Crafts and Trades (Zentralverband des Deutschen Handwerks - ZDH), which suggested that the Commission had lost touch with economic reality.' 56 In a joint declaration with the construction union (IG BAU), and in its official position presented to the Bundestag, the ZDH demanded revision of the directive to insure that receiving members states legislated-and enforced-minimum labour, social, health and environmental standards for service providers operating within their borders. ${ }^{57}$ Between these extremes, a common position evolved among most organised representatives of business-including the peak producers' and employers' associations - that enthusiastically approved the draft's efforts to simplify bureaucratic procedures for cross-border establishment, but remained sceptical about its impact on labour markets. Most regarded the expectation that member states of origin could or would enforce the behaviour of their service providers in other member states as unrealistic. Consequently, they demanded revision of the directive to remove provisions-especially Articles 24 \& 25-that conflicted with existing EU legislation and the Posted Workers Directive (96/71/EC) in particular.58 The Federation of German Industry (BDI) insisted that the Posted Workers Directive be given unambiguous precedence over the Services Directive in employment matters arising from

55 Arbeitsgemeinschaft Selbstaendiger Unternehmer e.V. (ASU), 'Schriftliche Stellungnahme zur oeffentliche Anhörung von Sachverstaendigen am 30. Mai 2005 in Berlin zum Vorschlag für eine Richtlinie des Europäische Parlaments und des Rates über Dienstleistungen im Binnenmarkt', Deutscher Bundestag, Ausschuss fuer Wirtschaft und Arbeit 15. Wahlperiode, May 19, 2005.

56 ZDH 'Handwerk begrüsst Überarbeitung der Dienstleistungsrichtlinie', Zentralverband des deutschen Handwerks, February 3, 2005, available at: <http:// www.zdh.de/ presse/ pressemeldungen/ archiv-pressemeldungen/ handwerkbegruesst-ueberarbeitung-der-dienstleistungsrichtlinie.html>.

$57 \mathrm{ZDH}$ 'EU-Dienstleistungsrichtlinie: Nur die vollständige Überarbeitung sichert fairen Wettbewerb - Gemeinsame Pressemitteilung von IG Bau and ZDH', Zentralverband des deutschen Handwerks, April 20, 2005, available at:

$<$ <ttp:// www.zdh.de/ presse/ pressemeldungen/ archiv-pressemeldungen/ eu-

dienstleistungsrichtlinie-nur-die-vollstaendige-ueberarbeitung-sichert-fairen-

wettbewerb.html>; ZDH 'Schriftliche Stellungnahme zur oeffentliche Anhörung von Sachverstaendigen am 30. Mai 2005 in Berlin zum Vorschlag für eine Richtlinie des Europäische Parlaments und des Rates über Dienstleistungen im Binnenmarkt', Deutscher Bundestag, Ausschuss fuer Wirtschaft und Arbeit 15. Wahlperiode, May 19, 2005.

58 BGA 'Schriftliche Stellungnahme zur oeffentliche Anhörung von Sachverstaendigen am 30. Mai 2005 in Berlin zum Vorschlag für eine Richtlinie des Europäische Parlaments und des Rates über Dienstleistungen im Binnenmarkt', Deutscher Bundestag, Ausschuss fuer Wirtschaft und Arbeit 15. Wahlperiode, May 25, 2005; BDA 'Presse-Information Nr.76/ 2004: Arbeitgeberpräsident Dr. Dieter Hundt: Vorrang für Wachstum und Beschäftigung in Europa-Binnenmarkt für Dienstleistung schnell vollenden', December 8, 2004, available at: http:// www.bda-online.de/ www/ bdaonline.nsf/id/ 29D43051973CC2F1C1256F64003957A2; DIHK 'Schriftliche Stellungnahme zur oeffentliche Anhörung von Sachverstaendigen am 30. Mai 2005 in Berlin zum Vorschlag für eine Richtlinie des Europäische Parlaments und des Rates über Dienstleistungen im Binnenmarkt', Deutscher Bundestag, Ausschuss fuer Wirtschaft und Arbeit 15. Wahlperiode, May 18, 2005; HDB 'Schriftliche Stellungnahme zur oeffentliche Anhörung von Sachverstaendigen am 30. Mai 2005 in Berlin zum Vorschlag für eine Richtlinie des Europäische Parlaments und des Rates über Dienstleistungen im Binnenmarkt', Deutscher Bundestag, Ausschuss fuer Wirtschaft und Arbeit 15. Wahlperiode, May 26, 2005. 
cross-border provision of services. ${ }^{59}$ Representatives of German business and employers greeted service market integration but remained deeply concerned about the draft directive's impact on labour markets.

The business community's ambivalence toward the draft directive reflects, at least partially, labour's role in production, particularly in Germany's core exporting industries. Space limitations preclude a full description of the complex, interdependent set of state and social institutions that underlie what is described as Diversified Quality Production (DQP), Coordinated Market Economy (CME), and Rhenisch or German Capitalism. ${ }^{60}$ Important for this study is how these models explain the goods German firms export and the role of labour in their production.

For decades, the Federal Republic of Germany has led the world in terms of per capita exports and often absolute exports. Germans export high valueadded producer goods (e.g., machine tools and industrial chemicals) and transportation equipment. As the term diversified quality production suggests, German exporters compete on world markets less on the basis of price and more often on an ability to design and deliver products on terms suited to customers' needs. The capacity to adjust output fluidly to diverse and changing customer demands requires firms to maintain skilled and flexible work forces that are tightly integrated into production decisions.

The institutionalised, 'dual' representation of labour, in sectoral unions as well as firm- and plant-level works councils, facilitates this integration. It blurs distinctions between management and labour within firms. 61 Statutes guarantee works councillors influence over the organisation of work within firms, while authority over issues normally placed in contracts-particularly wages - are reserved for negotiations between sectoral unions and employers associations. ${ }^{62}$ This system institutionalises cooperation between firm managers and employees where they have parallel interests-namely, in maintaining firm competitiveness. At the same time, it moves issues where management and labour have conflicting interests-such as over wage levelsoutside the firm. A critical result of this 'dual' representation of labour is a maintenance of internal 'peace' within firms that permits them to respond flexibly to shifting market conditions and consumer demands. As turbulence and the stringent requirements of just-in-time production increasingly shape competition on world markets, internally peaceful and flexible German firms

\footnotetext{
59 BDI 'Schriftliche Stellungnahme zur oeffentliche Anhörung von Sachverstaendigen am 30. Mai 2005 in Berlin zum Vorschlag für eine Richtlinie des Europäische Parlaments und des Rates über Dienstleistungen im Binnenmarkt', Deutscher Bundestag, Ausschuss fuer Wirtschaft und Arbeit 15. Wahlperiode, May 23, 2005.

60 M. Albert, Capitalism versus capitalism, New York: Four Walls Eight Windows, 1993; P. A. Hall and D. W. Soskice, 'An introduction to varieties of capitalism' in Varieties of capitalism: The institutional foundations of comparative advantage, Oxford University Press, USA, 2001, pp. 1-68; W. Streeck, 'German capitalism: does it exist? Can it survive?' in C. Crouch and W. Streeck (eds.), Political economy of modern capitalism, Sage Publications Ltd, 1997, pp. 33-54.

61 K. A Thelen, Union of parts, Ithaca, N.Y. and London: Cornell University Press, 1991.

62 Streeck, 'German capitalism', op. cit.
} 
have demonstrated themselves to be quite competitive. ${ }^{63}$ It is this internal peace and flexibility and, therefore, external competitiveness that many German employers fear they will lose if the post-war system of industrial relations erodes too far. Thus, scepticism toward the country-of-origin principle was situated not only among craftsman and construction firms that might have to compete against lower-paid workers from Central and Eastern Europe, but also among Germany's leading export firms. ${ }^{64}$

Given this constellation of societal interests, Germany's two largest political camps, the SPD and CDU/CSU, found themselves united in resistance to inclusion of the country-of-origin principle in the draft. In late 2004 and early 2005 prominent members of Schröder's Red-Green cabinet had, in fact, voiced support for the Commission draft.65 As public insecurity over unemployment and internal opposition to the Agenda 2010 swelled within the SPD, however, it was Chancellor Schröder, together with French President Chirac, who pressured the Commission to redraft the directive. ${ }^{66}$

The popular resistance rising against liberalisation in Germany and the EU not only split the SPD and forced Schröder to call a general election 12 months early, but it also swept up the Centre Right CDU/CSU. Badly misjudging the popular mood, CDU Chancellor candidate Angela Merkel ran a neo-liberal campaign and watched a $17 \%$ lead in opinion polls melt to less than one percent of the vote in two months. ${ }^{67}$ Prior to the election the representative of employees' interests inside the CDU, the CDA (Christlich-Demokratische Arbeitnehmerschaft), criticised the country-of-origin principle sharply. 68 Immediately after the election CDU delegations in the state parliaments of Baden-Württemburg (BW), Schleswig-Holstein (SH) and North RhineWestphalia (NRW) joined with the SPD and other parties to pass resolutions demanding reform of the draft directive. ${ }^{69}$ For a time after the 2005 election,

63 M. Piore and C. Sabel, The second industrial divide: possibilities for prosperity, New York: Basic Books, 1984; Thelen 'Why German employers', op. cit.

64 D. Creutzberg, 'Widerstand gegen Servicerichtlinie wächst', Handelsblatt.com, April 15, 2005, available at: <www.handelsblatt.com/News>.

65 Alexander Hagelüken, 'SPD streitet ueber Dienstleistungsmaerkte', Sueddeutsche Zeitung, January 10, 2005, sec. Wirtschaft.

66 Der Spiegel, 'Keine deutsche Stellungnahme?', Der Spiegel, March 14, 2005.

67 Forschungsgruppe Wahlen, 'Sonntagsfrage - Forschungsgruppe Wahlen 2002-2005 (Projektion)', Wahlen, Wahlrecht und Wahlsysteme, available at: <http:// www.wahlrecht.de/ umfragen/ politbarometer/ politbarometer-2005.htm>.

68 E. Brok, 'Dienstleistungsrichtlinie: ein neuer Ansatz ist notwendig', Soziale Ordnung, No. 4, 2005, pp. 12-13.

69 V. Netzhammer, Wirtschaftsausschuss fordert Änderungen am Entwurf der EUDienstleistungsrichtlinie', J anuary 23, 2006, available at: <http://www.veronikanetzhammer.de/pdf/ dienstleistungsrichtlinie.pdf>; plenum-online, 'Landtagsparteien machen mobil gegen EU-Dienstleistungsrichtlinie', plenum-online, der Landtag SchleswigHolstein, J anuary 2006, available at:

<http:// www.landtag.ltsh.de/ plenumonline/januar2006/texte/11_12_kombilohn_dienstleist ungsrichtlinie.htm>; CDU NRW 'Dienstleistungserbringung innerhalb der EU zu fairen Bedingungen sichergestellt', CDU Landtagsfraktion NRW, March 24, 2006, available at: $<\mathrm{http}: / /$ cdu-nrw-

fraktion.de/ index.php?id=405\&tx ttnews $\% 5 B$ cat $\% 5 D=24 \&$ tx ttnews $\% 5 B p S \% 5 D=114116760$ 0\&tx_ttnews $\% 5 \mathrm{BpL} \% 5 \mathrm{D}=267479 \overline{9} \& \mathrm{tx}$ ttnews $\% 5 \mathrm{Barc} \% 5 \mathrm{D}=1 \overline{\mathrm{\delta}} \mathrm{tx}$ ttnews $\% 5 \mathrm{Bpointer} \% 5 \mathrm{D}=1 \mathcal{E}$ tx ttnews\%5Btt news\%5D=1153\&tx ttnews\%5BbackPid\%5D=83̄\&cHash=a458c6e525>. 
advocates of 'social' Europe overwhelmed liberals within the CDU and the Grand Coalition of CDU/ CSU-SPD.

German politicians and the German government were instrumental in building the coalition that produced the European Parliament's (EP) amended draft of the directive and the Common Position that emerged from the Council. ${ }^{70}$ As rapporteur and coordinator, Evelyn Gebhardt, MEP (PSE/SPD), led the effort to remove the country-of-origin principle and limit the draft's scope within the European Parliament. Chairman of the EP Socialist Group, Martin Schulz (SPD), convened an 'informal group' with the European Peoples Party (EPP) leadership to 'monitor' the directive's legislative progress. ${ }^{71} \mathrm{In}$ February 2006, a PSE-EPP coalition amended the Commission's draft directive to strike the country-of-origin principle, limit the directive's scope and remove employment regulation from its field of impact. In a press release on the day of the EP vote, the German government applauded the efforts of 'the two great people's parties (Volksparteien) in the European Parliament in adopting a common line on the Service Directive that considers its social as well as economic consequences (Aspekte).' 72 It announced that the German government would 'participate in the subsequent negotiations within the Council constructively.'

The same press release also provides insight into the German government's motivation for removing employment regulation from the directive's scope. It proclaimed the German Grand Coalition's 'expressed will' to take timely legislative measures to protect the German labour market from wage dumping. ...' In doing so, it commissioned a working group under the Federal Minister for Labour and Social Policy to consider the issues of minimum wages and the posted workers law (AEntG) arising from the EU Services Directive. By removing the country-of-origin principle and labour policy generally from the directive's field of impact, Germans created a window of opportunity for domestic reform of labour market regulations before the internal market for services comes into operation.

The intense resistance to the Bolkestein Draft within Germany reflects the peculiar organisation of German labour markets and the expected impact of integration on that organisation. Unions and employers expected the introduction of an integrated service market, as envisioned by the Commission's initial draft, to accelerate erosion of Germany's sectoral, corporatist labour market regulations in favour of a decentralised alternative. Erosion seemed to threaten not only unions and their core constituencies of skilled industrial workers, trades workers and construction industries, but also exporting firms that relied on the post-war system of labour representation to maintain shop floor peace and flexibility. Given the breadth of the forces resisting the directive's original formulation-and the weak support for it-Germany's political leaders unified to remove labour policy from the directive's scope. They could not-and did not want to-prevent

\footnotetext{
$70 \mathrm{~S} \& \mathrm{D}$, op. cit.

71 S \& D Ibid.

72 Presse- und Informationsamt der Bundesregierung, 'Stellungnahme der Bundesregierung zur Abstimmung über die Dienstleistungsrichtlinie im Europäischen Parlament, Pressemitteilung Nr. 43,' February 16, 2006.
} 
service market integration. Rather, they hoped to undertake the labour market reforms that integration would require domestically rather than in the context of European legislation. The revised services directive opened a window of opportunity for such reform that will last until 2010-11. The next section considers the choices about institutional change in labour market regulations that Germans subsequently confronted.

\section{Institutional Change in German Labour Markets: Bringing the State (Back) in?}

Removal of employment regulation from the Directive's scope has postponed-but not removed-the need for institutional reform in German labour markets. One way or another, Germans will resolve the tension between the heterogeneous labour market regulations and Treaty prohibitions against discrimination. Before labour markets open to employees from Central and Eastern Europe in 2011, Germans will choose the path of institutional change. Figure 1 offers four ideal paths to institutional change based on whether Germans choose liberal or illiberal regulations and whether such measures are introduced incrementally or by a radical legislated break. The following considers each of these options, evaluating the consequences and likelihood of each.

\section{Figure 1}

\section{Paths to Change in German Labour Market I nstitutions}

\begin{tabular}{|l|l|l|l|}
\hline & & \multicolumn{2}{|l|}{ Scope of Change } \\
\hline & Radical & Incremental \\
\hline $\begin{array}{l}\text { Direction } \\
\text { change }\end{array}$ & Liberal & $\begin{array}{l}\text { 1. } \\
\text { Decentralisation }\end{array}$ & 2. Erosion \\
\cline { 2 - 4 } & Illiberal & $\begin{array}{l}\text { 3. } \begin{array}{c}\text { Legislated } \\
\text { Standards }\end{array} \\
\text { M. }\end{array}$ & $\begin{array}{l}\text { 4. Reinforced } \\
\text { Minimum Wage }\end{array}$ \\
\hline
\end{tabular}

\section{1. 'Decentralisation'}

The meaning of 'radical' change is, of course, relative to the origin from which change proceeds. A complete decentralisation from agreements negotiated between sectoral unions and employers associations to contracts agreed between individual employers and employees is unlikely. This would require revision-or, at least, radical reinterpretation-of the freedom of association guaranteed by the Basic Law. Other forms of decentralisation are conceivable, however. Voices within the liberal Free Democratic Party (FDP), for example, have advocated revising the Works Constitution Law (specifically, Art.77 Para.3 BetrVG) to lift restrictions on works councils' rights to negotiate issues 
such as wages. While experience with the Services Directive demonstrates unions' capacity to mobilise politically to prevent legislated decentralisation of industrial relations, their ability to resist more gradual movement may be restricted.

Legislation at the level of the European Union also presents a possibility for 'radical liberalisation.' Decisions by the European Court of J ustice in the socalled Laval (C-341/05), Viking (C-438/05) and Rüffert (C-346/06) cases have called into question the application of minimum employment standards set out in the Posted Workers Directive (96/71/EC) by collective bargaining arrangements between social partners. ${ }^{73}$ In particular, the Court ruled that application of minimum standards through flexible collective bargaining agreements were too opaque for foreign investors and, therefore, represented an unacceptable reason to restrict the freedom to provide services. ${ }^{74}$ The implications of these ruling for Member States which set minimum employment standards by collective agreements are still being worked out.

\section{2. 'Erosion'}

Incremental decay of the sectoral industrial relations system toward decentralisation, or-as Anke Hassel calls it-'erosion,' precipitated the contemporary dilemma. ${ }^{75}$ It is also the default option for change. Some observers argue that German employers are bringing about decentralisation without altering the formal institutions of labour market regulation and codetermination. ${ }^{76}$ So-called 'firm-level alliances for jobs' have-officially and unofficially-tested the limits on what works councillors may negotiate. ${ }^{77}$ Unions have, of course, resisted moving wage negotiations back into firms, but, as previously noted, their capacity to resist these more gradual changes are limited. Accordingly, movement toward greater decentralisation is likely to be incremental and dependent on the degree of cohesion that prevails among employers.

This situation is the product of a collective action problem in the industrial relations system combined with the 'rigid' structure of Germany's political institutions. Erosion proceeds because rising costs tempt small- and mediumsized firms to 'stretch' or abandon the sectoral collective bargaining framework. ${ }^{78}$ Their defection is motivated by the fact that large firms dominate sectoral associations and squeeze smaller firms from two directions.

\footnotetext{
73 European Trade Union Institute (ETUI), Viking - Laval - Rüffert - Luxembourg / Headline issues / European Trade Union Institute (ETUI) - ETUI', Research, Education, Health \& Safety, available at: <http:// www.etui.org/ Headline-issues/ Viking-Laval-RueffertLuxembourg>; M. Whitall, Unions fear ECJ ruling in Laval case could lead to social dumping,, Article, EIRO-online, February 25, 2008, available at: <http:// www.eurofound.europa.eu/ eiro/2008/01/ articles/ eu0801019i.htm>.

${ }^{74}$ Whitall, op. cit.

75 Hassel, 'The erosion', op. cit.; Hassel, 'The erosion continues', op.cit.

${ }^{76}$ D. Kinderman, 'Pressure from without, subversion from within: The Two-Pronged German Employer Offensive', Comparative European Politics, Vol. 3, December 2005, pp. 432-463; G. Menz, 'Old bottles - new wine: The new dynamics of industrial relations', German Politics, Vol. 14, No. 2, 2005, pp. 196-207.

77 Hassel, The erosion', op. cit.; and Hassel, The erosion continues', op. cit.

78 Thelen 'Why German employers', op. cit.
} 
On the one hand, large firms are more able to pay higher wages to maintain peace on the shop floor and, therefore, may set wages above a level that which their smaller counterparts can maintain. On the other hand, large firms can also pass some of their increased wage costs on to their smaller suppliers. This has led many smaller employers to 'stretch' sectoral agreements by demanding 'opening clauses' that permit them to renegotiate critical elements-including wage rates - at the firm and plant level, or to depart from the collective bargaining system altogether. ${ }^{79}$ Outside the collective bargaining system, these employers continue to enjoy many of its benefits, including noncompetitive markets for skilled labour and orderly wage bargaining rounds. ${ }^{80}$ As with all collective action problems, however, there is a danger that the 'tyranny of small decisions,' will undermine provision of collective benefits. If large employers feel the costs of maintaining the system outweigh its benefits, they may also abandon it. German employers are cognisant of the costs of collapse, however, and recent developments in airline, railroad and healthcare systems offer sobering reminders of less pleasant alternatives to centralised industrial relations. Some employers also remember the 1960s and early 1970s when, in a booming economy, the collective bargaining system served to reduce upward pressures on wages rather than put a floor under their downward movement. Thus, erosion of the post-war industrial relations system threatens many interests, including those of many employers, and incites calls to stop the decay. It is not clear, however, that even a preponderance of societal interests can prevent this process.

The structure of German political institutions inhibits legislative efforts to shore up the existing system of industrial relations. Germany's decentralised, 'semi-sovereign' political institutions provide many opportunities for minorities to block legislated reform. ${ }^{81}$ First, major reforms often need to gain support from differing partisan majorities in the upper and lower houses of the German parliament. Second, unions and employers wishing to resist change have used the FRG's legal system and its strong protection of Tarifautonomie to block government attempts to reform labour markets. ${ }^{82}$ Thus, any attempt to stem erosion and avoid default liberalisation by legislating labour market reforms will require a very broad coalition supporting it.

\section{3. 'Legislated Standards'}

For many of the reasons mentioned above transformation of the German system toward one in which the state determines the principle conditions of

\footnotetext{
79 Thelen, Ibid.; Georg Menz, 'Old bottle - new wine', op. cit.; Kinderman, op. cit.

80 Thelen, Why German employers', op. cit., p. 157.

${ }^{81}$ F. Scharpf, 'No Exit from the J oint Decision Trap? Can German Federalism Reform Itself?', EUI-RSCAS Working Papers, 2005; P. Katzenstein, Policy and politics in West Germany: the growth of a semi-sovereign state, Philadelphia: Temple University Press, 1987; M. G. Schmidt, 'Germany: The Grand Coalition State' in J . Colomer (ed.), Political Institutions in Europe, London, 2nd ed, London and New York: Routledge, 2002, pp. 57- 93.

82 W. Streeck, 'Industrial relations: From state weakness as strength to state weakness as weakness. Welfare corporatism and the private use of the public interest' in S. Green and W. E. Paterson (eds.), Governance in contemporary Germany: the semisovereign state revisited, Cambridge: Cambridge University Press, 2005, pp. 138-164; Streeck and Hassel, op. cit.; and Ziegler and Leslie, op. cit.
} 
employment is equally unlikely. Even the prospect of legislating a floor underneath wages has provoked resistance from not only employers, but also some unions. In particular unions representing skilled employees in the metalworking/engineering and chemical industries, IG Metall and IG BCE, resist weakening Tarifautonomie and moving wage determination to the [legislative arena] where [unions], under certain circumstances, have little influence.'83 Since 2004, the SPD has advocated introduction of 'minimum wages' and, in 2006, the DGB adopted a similar position. This formulation is misleading and should not be equated with a legislated minimum wage. Unions and employer resistance to state intervention at the expense of their influence is sufficient to prevent large scale reorganisation of labour market institutions along, say, French lines. This, however, does not mean that the state is not being drawn increasingly into German labour markets.

\section{Reinforced Corporatism + Minimum Wage}

The fourth-and most likely-path for change in German labour market institutions involves state intervention to reinforce corporatism and 'minimum wages.' As noted above, 'minimum wages'-and many employment standards - can be set by legislation, contract or a combination of the two. Provisions in some countries permit state actors to declare contract agreements negotiated between representative unions and employers organisations binding for all employment in a given sector and/ or region. The EU Posted Workers Directive (96/71) explicitly allows such arrangements and the German Posted Workers Law (AEntG) permits the Federal Minister for Labour and Social Policy to declare contracts universally binding in those sectors that are under its jurisdiction and that negotiate contracts for the entire territory of the FRG or in all of its regions. ${ }^{84}$ As noted above, the Posted Workers Law has been extended from the building industry to cover other sectors. Some voices, particularly within the unions, advocate extension of the Posted Workers Law across all sectors, enabling German unions and employers associations to set a wage minimum which would also bind foreign employers operating within the FRG. 85 There are several technical problems associated with such a solution. Many sectors do not negotiate blanket contracts covering all of the FRG, or each of its territories or have collective bargaining at all. Furthermore, even in some sectors with collective bargaining (e.g. security guards, hairdressers, hotel and hospitality), contractual minimum wages are already below the poverty level. ${ }^{86}$ Low wages and gaps in the collective bargaining system have led analysts within the SPD, the Left Party and, service sector unions (Ver.di, NGG) to advocate a legal minimum wage in addition to reinforcing the contractual system.

Mechanisms for determining legislated minimum wages can also assume different forms that give greater or lesser powers to the state and social actors. Some countries, such as the US, introduce minimum wages as a simple

83 Guggemos in R. Janssen, 'Der Mindestlohn in der gewerkschaftliche Debatte: Kozepte, Konflikte, Strategien' in G. Sterkel, T. Schulten, and J . Wiedemuth (eds.), Mindestlöhne gegen Lohndumping, Hamburg: VSA-Verlag, 2006, p. 266.

${ }^{84}$ Bispinck and Schulten, op. cit.

85 DGB Bundesvorstand, op. cit.

${ }^{86}$ Bispinck and Schulten, op. cit.; Bispinck and Schäfer, op. cit. 
legislative act, while others require consultation with (e.g. UK) or even consent from (e.g. Belgium) unions and employers. ${ }^{87}$ Thus, while a legislated minimum wages-like universally binding contractual wages-have the force of law, the determination of minimum wage levels may include a strong dose of corporatism. The role of corporate social actors in determining legal minimum wages, of course, depends on their inclusion in construction of institutions for setting minimum wages.

The political problems of reinforcing corporatist labour market regulation are more complicated than the technical problems. Both the extension of mechanisms making collective negotiations legally binding or the introduction of a legal minimum wage involves renegotiating and re-institutionalising the influence of employers' and employees' representatives in labour markets. The distributive effects of such institutional reform are enormous and the consequences long-lasting. Either extension of the Posted Workers Law or introduction of a legal minimum wage will increase state involvement in labour markets at the expense of Tarifautonomie. Increased state influence will raise union and employer concerns about the behaviour of future governments, making them hesitant to embrace reform. Furthermore, the structure of German legislative and judicial institutions may permit even relatively small minorities to block reforms. Thus, reform will require a broad social coalition. Employers and employees who benefit by preserving the core of the post-war industrial relations system will have to accommodate the interests of those who fall outside it. While this implies some degree of decentralisation of employment regulation it may also imply a need for increased capacity by employers associations and unions to ensure that decentralisation is not exploited for 'free riding.' The failure to build such a coalition raises the spectre of liberal decentralisation and the implications such a development will have for not only the welfare of (some) German employees and the competitiveness of German exporters. Broad German resistance to the original draft of the Services Directive suggests the potential for such a coalition, although its mobilisation for positive institutional reform presents a far more complicated project.

\section{Conclusion}

The strength and breadth of German opposition to the Bolkestein Draft reflects German labour markets' peculiar vulnerability to broad application of the country-of-origin principle as well as uncertainties arising from the ongoing liberalisation of these markets. For many Germans-including unions and employers as well as Christian and Social Democrats-the initial draft of the Services Directive threatened to advance, perhaps irretrievably, the erosion of Germany's post-war industrial relations system. Accordingly, this constellation of interests mobilised Germany's considerable influence in EU institutions to revise the draft and shift labour market reform to domestic legislative arenas. Revision of the Services Directive, however, has postponed reform of German labour markets, but it has not removed pressures driving that process.

${ }^{87}$ Schulten, op. cit. 
Service market integration and European integration, more broadly, are advancing the transformation of Germany's labour market institutions. Increasing integration of and competition in global markets-developments advanced by both European integration and German unification-have contributed to firm flight from employers' associations and erosion of Germany's post-war industrial relations system. This erosion set the stage on which introduction of the Bolkestein Draft provoked broad opposition in Germany. The success of this opposition, however, indicates that complete liberalisation of the post-war order is hardly a foregone conclusion. Indeed, very public 'debates' in Germany about shoring up the post-war system of sectoral bargaining by extending the scope of the Posted Workers Law (AEntG) or by introducing a legislated minimum wage are well under way. That said, nothing guarantees that a coalition united in resistance to European 'reform' of German labour market institutions can be sustained to carry out this delicate operation domestically.

The path Germans choose in the time remaining before European integration closes the 'window of opportunity' for domestic institutional reform is pregnant with insights about the impact of international market liberalisation on institutions of national political economies. These developments will add insight about what constellations of political/legislative institutions direct pressures for change toward liberalisation and where established interest organisations can exploit the institutional advantages of incumbency to shape developments. The outlines of a reinforced-and modified-form of corporatist industrial relations system are, for example, visible in the proposed extension of the Posted Workers Law and some proposals for a legislated minimum wage. These observations, in turn, raise questions about the process of institutional change and whether and how such change might take place incrementally. ${ }^{88}$ How close are the 'complementarities' between institutions in national economic 'models'?89 Can 'hybridised' arrangements, with corporatist and more liberal elements side-by-side, persist? ${ }^{90}$ Answers to such questions require time and comparative analysis.

\footnotetext{
88 Streeck and Thelen, op. cit.

89 R. Deeg, 'Complementarity and institutional change in capitalist systems', J ournal of European Public Policy, Vol. 14, No. 4, 2007, pp. 611- 630.

90 K. Dyson and S. Padgett, Introduction: Global, Rhineland or hybrid capitalism?', German Politics, Vol. 14, No. 2, 2005, pp. 115-24; Ziegler and Leslie, op. cit.
} 